Love as Pedagogy 


\section{Love as Pedagogy}

Tim Loreman

Concordia University College of Alberta, Edmonton, Canada

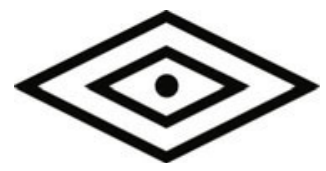

SENSE PUBLISHERS

ROTTERDAM/BOSTON/TAIPEI 
A C.I.P. record for this book is available from the Library of Congress.

ISBN: 978-94-6091-482-9 (paperback)

ISBN: 978-94-6091-483-6 (hardback)

ISBN: 978-94-6091-484-3 (e-book)

Published by: Sense Publishers,

P.O. Box 21858,

3001 AW Rotterdam,

The Netherlands

https://www.sensepublishers.com

Printed on acid-free paper

All Rights Reserved (C) 2011 Sense Publishers

No part of this work may be reproduced, stored in a retrieval system, or transmitted in any form or by any means, electronic, mechanical, photocopying, microfilming, recording or otherwise, without written permission from the Publisher, with the exception of any material supplied specifically for the purpose of being entered and executed on a computer system, for exclusive use by the purchaser of the work. 
DEDICATION

For my family. 



\section{TABLE OF CONTENTS}

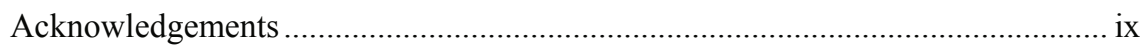

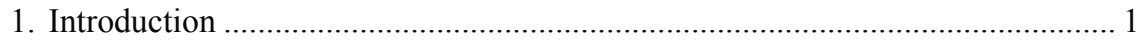

2. Kindness and Empathy in Pedagogy …......................................................... 15

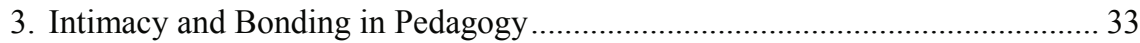

4. Sacrifice, Forgiveness and Pedagogy ……...................................................... 49

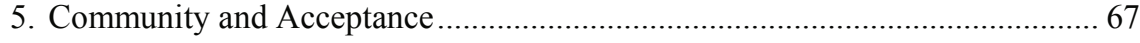

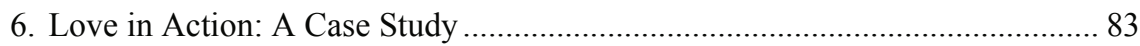

7. Infusing Love into Daily Pedagogy ….............................................................. 99

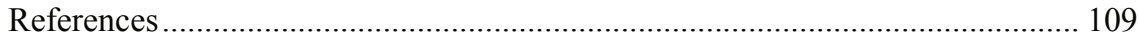





\section{ACKNOWLEDGEMENTS}

Without the support of my family this book could never have been written. Thank you for your love and encouragement.

Professor Chris Forlin at the Hong Kong Institute for Education was instrumental in helping to bring this project to completion. Chris showed all the qualities of an outstanding colleague, mentor, and friend as she kindly read through and offered helpful critiques of each chapter as I completed them one by one and sent them off to her. Her insights, encouragement, and willingness to edit my clumsy drafts on planes, trains, and at her desk are deeply appreciated. If this book has some semblance of quality it is largely due to her contribution.

I am grateful to the school district, school, and individual participants in the case study that forms the majority of Chapter Six for welcoming my research team and I. I would also like to thank my friends and collaborators in that team, especially Judy Lupart, Donna McGhie-Richmond, Rob McGarva, Kathy Hickey, Margaret Thompson, Jennifer Barber, Angie Irvine, and our research assistants from both Concordia University College of Alberta and the University of Alberta. Without this team the case study in Chapter Six could not have come to fruition.

Professor Nicola Cuomo and colleagues in the Giovanni Maria Bertin Department of Educational Science and the Institute of Advanced Studies at the University of Bologna in Italy are acknowledged and thanked. I am grateful for the hospitality afforded to me and the opportunities to discuss and the ideas contained in this book during my time there as a Senior Visiting Fellow in 2010.

In short, to a very large degree this work has been improved by the work of, and suggestions from, my family and many friends and colleagues, however, I did not always choose to take their advice and so accept full responsibility for any failings this work might have. 
